\title{
Correction to: Effect of precipitation on soil respiration in a temperate broad-leaved forest
}

Seok-Hee Jeong ${ }^{1}$, Ji-Young Eom ${ }^{1}$, Joo-Yeon Park' ${ }^{1}$ Jung-Hwa Chun ${ }^{2}$ and Jae-Seok Lee ${ }^{1 *}$

\section{Correction to: J Ecology Environ 42, 10 (2018) https://doi.org/10.1186/s41610-018-0071-6}

Following publication of the original article (Jeong et al. 2018), an error in Fig. 2 was noticed. The incorrect year was inserted on the X-axis. The corrected Fig. 2 is published in this correction article.

\section{Author details \\ 'Department of Biological science, Konkuk Universtiy, Seoul, South Korea. \\ ${ }^{2}$ Division of Forest Ecology, National Institute of Forest Science (NIFoS),}

Seoul, South Korea.

Published online: 07 December 2020

\section{Reference}

Jeong SH, Eom JY, Park JY, et al. Effect of precipitation on soil respiration in a temperate broad-leaved forest. J Ecology Environ. 2018;42:10 https://doi.org/ 10.1186/s41610-018-0071-6.

The original article can be found online at https://doi.org/10.1186/s41610018-0071-6.

* Correspondence: jaeseok@konkuk.ac.kr

'Department of Biological science, Konkuk Universtiy, Seoul, South Korea

Full list of author information is available at the end of the article

(c) The Author(s). 2020 Open Access This article is licensed under a Creative Commons Attribution 4.0 International License, which permits use, sharing, adaptation, distribution and reproduction in any medium or format, as long as you give appropriate credit to the original author(s) and the source, provide a link to the Creative Commons licence, and indicate if changes were made. The images or other third party material in this article are included in the article's Creative Commons licence, unless indicated otherwise in a credit line to the material. If material is not included in the article's Creative Commons licence and your intended use is not permitted by statutory regulation or exceeds the permitted use, you will need to obtain permission directly from the copyright holder. To view a copy of this licence, visit http://creativecommons.org/licenses/by/4.0/ 


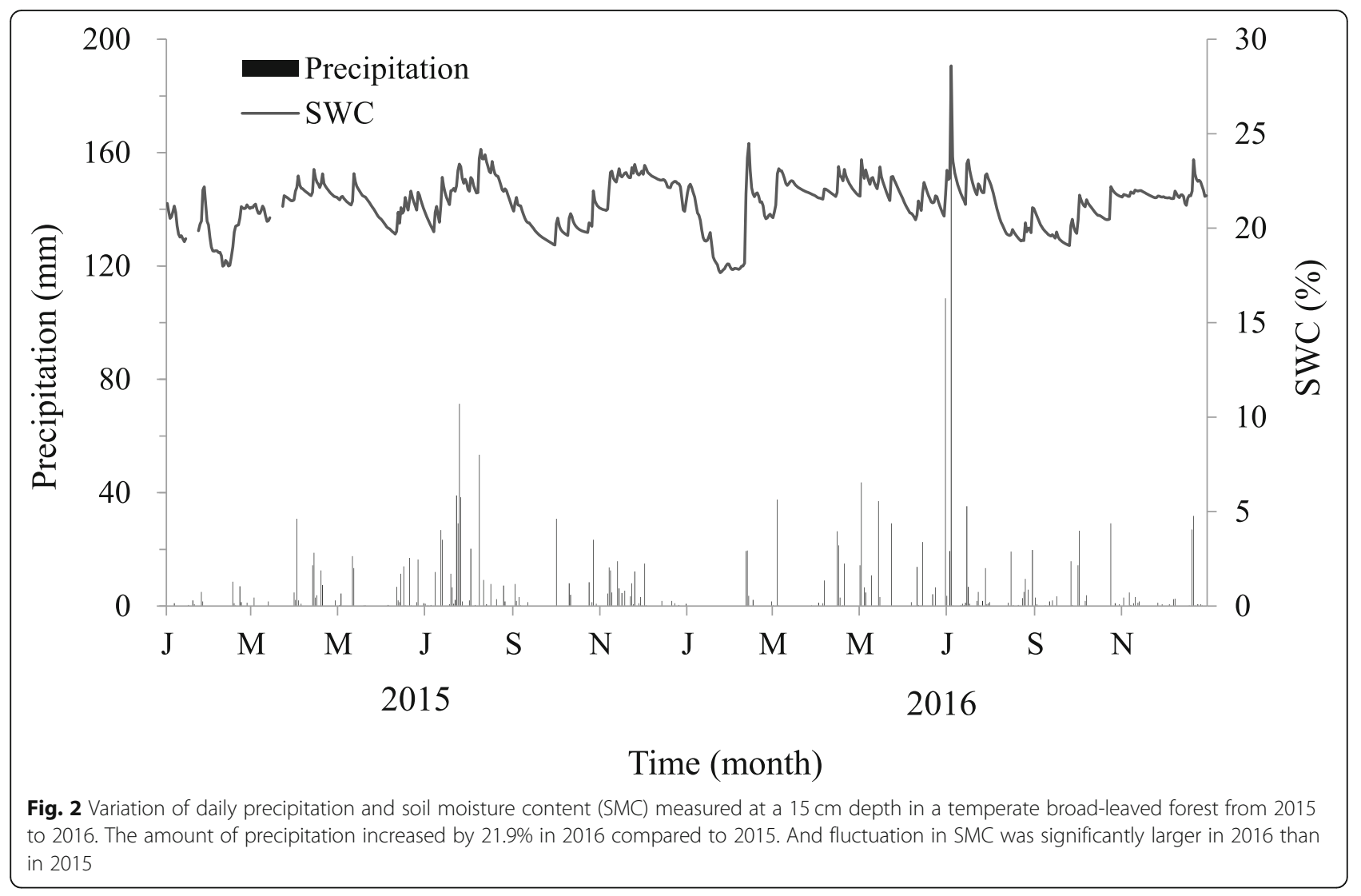

